Article

\title{
Globalization and Religion in Historical Perspective: A Paradoxical Relationship
}

\section{Luke M. Herrington}

Center for Global and International Studies, University of Kansas, 1541 Lilac Lane, Room 318, Lawrence, Kansas 66045, USA; E-Mail: 1mh6331@gmail.com

Received: 20 December 2012; in revised form: 5 February 2013 / Accepted: 4 March 2013 /

Published: 12 March 2013

\begin{abstract}
Religion has long been a driving force in the process of globalization. This idea is not controversial or novel thinking, nor is it meant to be. However, the dominant reasoning on the subject of globalization, expressed by authors like Thomas Friedman, places economics at the center of analysis, skewing focus from the ideational factors at work in this process. By expanding the definition of globalization to accommodate ideational factors and cultural exchange, religion's agency in the process can be enabled. Interestingly, the story of religion and globalization is in some ways the history of globalization, but it is riddled with paradoxes, including the agent-opponent paradox, the subject of this article. Religion and globalization have a co-constitutive relationship, but religious actors are both agents of globalization and principals in its backlash. While some actors might benefit from a mutually reinforcing relationship with globalization, others are marginalized in some way or another, so it is necessary to expose the links and wedges that allow for such a paradox. To that end, the concepts of globalization and religious actors must be defined, and the history of the agent-opponent paradox, from the Buddhists of the Silk Road to the Jubilee campaign of 2000, must be elucidated.
\end{abstract}

Keywords: globalization; religion; homogenization; anti-globalization backlash; religious actors

\section{Abbreviations}

CFR: Council on Foreign Relations; ESCWA: Economic and Social Commission for Western Asia; IMF: International Monetary Fund; ISAF: International Security Assistance Force; LON: League of 
Nations; NGO: Nongovernmental Organization; NRM: New Religious Movement; UK: United Kingdom; UN: United Nations; U.S.: United States of America; WTO: World Trade Organization.

\section{Introduction}

Religion has long been a driving force in the process of globalization. In fact, argues Reza Aslan, "no single force can be said to have had a greater impact on propelling globalization forward than religion, which has always sought to spread its message" beyond the ethnic and territorial frontiers of its origin ([1], p. 18; emphasis added). This idea, as shall be made apparent throughout this article, is not controversial or novel thinking, nor is it meant to be. However, the dominant reasoning on the subject of globalization, expressed by such influential thinkers as famed journalist Thomas Friedman, places economics at the center of analysis and skews focus away from the ideational factors at work in this process. Moreover, the economic-centric approach to the study of globalization is also a Western-centric approach hindered by its need to trace the origins of this phenomenon to some historically significant period in Europe's colonial-imperial past, such as the so-called Great Discoveries. Yet, globalization began long before European explorers set sail across the vast Atlantic Ocean on journeys that would eventually reveal the existence of the Americas - indeed, long before the term "globalization" was even coined. The economic-centric approach to globalization fails, in part, because a force more primal, more enduring, and more important, has been fueling this process for millennia - and that force is religion. Certainly, though it only represents a piece of the proverbial puzzle, in many ways to understand the story of religion and globalization is to understand the history of globalization.

This history reveals a problem I term the agent-opponent paradox. That is, in spite of the fact that religion and globalization have a uniquely co-constitutive relationship, the latter can impact religion in varying, sometimes paradoxical ways. The obvious explanation for this, as most people should understand, is that religion should not be treated as a monolith, a reality dictated by its sheer diversity and the world's almost incalculable number of religious actors. Nevertheless, scholars should become comfortable with this strange relationship, especially since religion regularly exposes the paradoxes of globalization. For example, it was once predicted that the forces of globalization - modernization and democratization to name two-would lead to the inexorable decline and privatization of religion, but today's global resurgence in religion is itself driven by many of these same forces. The agent-opponent problem is another such paradox, and it is caused by the fact that religious actors, in addition to being agents of globalization, actually function as principals in its backlash. Considering the fact that globalization - through a process known as homogenization - can easily upset cultural moors, it should come as no surprise that this powerful force is perceived by some religious actors as an antagonistic source of disruption; nor should it come as a surprise, regardless of globalization's incarnation, be it in the form of neoliberal economic policy, religio-cultural homogenization, Americanization, imperialism, or something else, that this disruption can foster opposition among those effected actors seeking protection from the seemingly relentless tides of globalization, even if some of those same actors might be implicated in its very genesis. Social scientists might characterize this as a kind of negative feedback loop, but the truth is that religion-globalization relationships are not couched exclusively in conflict. For this reason, the agent-opponent paradox is the subject of this article. 
The multi-case, qualitative narrative that follows recognizes that different religious actors from varying traditions have unique experiences. Thanks to existence in different physical or temporal contexts, this is true even of those actors from within the same tradition. Some actors benefit from a mutually reinforcing relationship with globalization, while others are marginalized in one way or another, so it is necessary to expose some of the specific links and wedges that allow for such a paradox. To that end, globalization must be defined and its temporal context must be delineated. Because some perceive globalization to be little more than a modern phenomenon, they may be skeptical of religion's agency in the process. In fact, if globalization began with the collapse of the Berlin Wall, as Friedman might suggest, then even John O'Sullivan, whose luculent analysis of the Vatican's role in defeating communism portrays Pope John Paul II as a founder of the post-Cold War era, would be hard pressed to aver the role of the religious actor as a globalizing force ([2], p. 7; [3]). So, while it may be tempting to study globalization exclusively through a post-Westphalian lens, the only purpose this serves is to reinforce the economic-centric approach to the subject. However, by looking at globalization as a long historical trend, or as a series of such trends, the definition of globalization can be expanded to accommodate ideational factors and cultural exchange, whilst also enabling religion's agency in the process.

After addressing the definition of globalization, I will return to the subject of the agent-opponent paradox in a historical analysis that explores the role of religious actors as agents of globalization. Beginning with the spread of Judaism and Buddhism along the Silk Road in ancient times, this section will first illustrate that religious and economic actors have been co-equal partners in the process of globalization for millennia. However, missionary activity and religious pilgrimages - especially among Buddhists, Christians, and Muslims - have also been integral sources of globalization distinct from economic practices like trade. The following section will present the "homogenization thesis," and introduce the subject of the globalization backlash. It will highlight the role of Jubilee 2000 at the so-called "Battle of Seattle," a widely recognized moment of some importance to the globalization backlash. Furthermore, it will argue that the globalization backlash is, in some ways, a response to a perceived asymmetric power imbalance that makes some hegemonic powers, like the Roman Empire in the distance past or the U.S. today, appear responsible for the exploitation and cultural disruption commonly associated with globalization. Such power imbalances explain why some today might see globalization as synonymous with Americanization and Westernization, which is why even an incident such as the Iranian Revolution can be presented as a case in the globalization backlash. However, as the case of American Christian nationalist anti-globalization conspiracy theories indicates, not all such protests can be seen as anti-Western or anti-American. I will conclude with the assertion that understanding the agent-opponent paradox is important at least in part because it poses security challenges for the international community. First, however, is it necessary to define religion?

\section{Defining Religion}

Religion and globalization might seem like equally ineffable concepts. Yet, the concept of religion has existed far longer than the latter, and as such, so have debates about its meaning. In fact, arguments over the definition of religion consumed sociologists, anthropologists, and scholars of religious studies throughout much of the $20^{\text {th }}$ century. Attempting to define religion may still be a useful epistemological 
exercise, but the fact that this debate persist today may demonstrate that it is largely unresolvable. Indeed, hardly a definition arrived at can satisfy the would-be critic, for such a definition would almost inevitably be riddled with some kind of value judgment that might leave it biased in favor of one putative religion at the expense or exclusion of another. Nevertheless, by borrowing from the core ontological and epistemological tenets of reflexivity and subjectivism respectively, one can bypass this problem (albeit in a limited fashion as this approach may make it too difficult to operationalize the concept of religion). First, in the Giddensian approach to reflexivity, one must recognize that the constitution of social life empowers researchers to "influence what they study" through knowledge production [4]. Second, the subjectivist epistemology common to social constructivist thought recognizes that since an individual's understanding of the world is built in his or her own mind, knowledge of the world cannot be completely objective. Consequently, individuals must rely on their own instincts to inform their conceptions of what "religion" is, for, as religious studies scholar W. Richard Comstock avers, "Augustine's famous observation about time applies with equal force to religion; if not asked, we know what it is; if asked, we do not know" ([5], p. 499).

Instead of trying to define the concept of religion - which is beyond the scope of the present study anyway - it might be more useful to employ a partial typology that allows for the recognition of religion's agency in the process of globalization. By speaking of religious actors, as opposed to the broader concept of religion itself, one is speaking of individuals, groups, and organizations that act on consistent messages regarding the relationship between religion, politics, and society at-large. Said differently, they organize for action based on their espoused religious beliefs. Of course, as Monica Duffy Toft, Daniel Philpot, and Timothy Samuel Shah caution, these actors "might well be a part of a larger religious entity" or they may even be part of "a collectivity whose members themselves are not unanimous," but the fact remains that the "religious actors" concept largely forgoes the problems one might encounter if speaking about religion in general ([6], pp. 22-23).

\section{Defining and Delineating Globalization}

Unlike "religion," enough confusion exists around the concept of globalization that it is necessary to elucidate this problematic phenomenon by tackling its own definitional dilemmas. Like religion, globalization is a challenging concept to define, not least because the dominant reasoning on the subject suggests that it is, above all, an economic process. For example, the UN ESCWA describes it as the economic phenomenon responsible for reducing barriers to "the flow of goods, capital, services and the movement of [labor]" [7]. That globalization is portrayed in such definitions as an exclusively economic occurrence would likely not bother experts such as Friedman, who himself views globalization as an international system driven by capitalism, free trade, the spread of technology and information, and the "inexorable integration of markets, nation-states and technologies to a degree never witnessed before" ([2], pp. 9, 46-48, 60-61). Kevin H. O’Rourke and Jeffrey G. Williamson would likewise raise little protest. They see globalization as "the integration of international commodity markets" ([8], p. 25). This economic-centric perspective is so thoroughly ingrained in the mainstream understanding of globalization, that the centrality of economics is even echoed in the dictionary definition of the term; Merriam-Webster defines globalization as "the development of an 
increasingly integrated global economy marked especially by [...]the tapping of cheaper foreign labor markets" [9].

Defining this ubiquitous force in purely economic terms limns an unfinished portrait incapable of illustrating the true scope and magnitude of globalization, which essentially renders the economic-centric approach inadequate. After all, globalization may involve the movement and flow of capital, goods, and technology, but it also involves the flow of people, ideas, knowledge, and culture. Of course, major businesses, financial firms, and multinational corporations may be a driving force behind modern globalization, but as Susanne Hoeber Rudolph contends, religious actors "are among the oldest of the transnationals." She maintains that Sufis, Catholics, and Buddhists, to name a few, have each "carried word and praxis across vast spaces before those places became nation-states or even states" ([10], p. 1). Thus, religious actors have been vital to the history of globalization. Yet, the economic approach to defining globalization obscures this reality by insinuating that globalization is an exclusively modern phenomenon. Consequently, before this concept can be properly defined it is essential to ask: when did globalization begin? To answer, some researchers turn first to Friedman, a leading figure in the study of globalization. In The Lexus and the Olive Tree he argues that globalization, in its current incarnation, is a neoteric construction-the systemic realization of the early 1990s victory of capitalism over communism. Historically, Friedman only recognizes one other such period of international integration as worthy of the "globalization" label. In his view, what might be dubbed "Globalization Round I" only lasted from the mid-1800s to the late 1920s, ultimately ending due to the disruptive influence of the Great Depression. Subsequently, the global trifurcation of the Cold War, maintains Freidman, created a slow, "divided-up, chopped-up place," where virtually every country in the world fell into disconnected communist, capitalist, and neutral camps. Therefore, the resumption of globalization-“Round II," in Friedman's parlance_-did not occur until the Cold War ended ([2], pp. xvi-xvii, 7-8).

David M. Smick concedes that there is nothing particularly new about the world's current economic situation, so while he might agree that the forces propelling globalization began much earlier than the 1990s, even he is unwilling to break with Friedman's paradigm. Smick acknowledges the existence of a $19^{\text {th }}$ century epoch of globalization, but he really only admits that the current phase of globalization began within the last quarter-century, with the integration of the world's financial markets. Since countries like the U.S. were enmeshed in a closed economic system prior to the $1980 \mathrm{~s}$, it is the integration of the financial markets, Smick argues, that "got globalization started." Thus, the era of free trade marked the dawn of globalization, which was itself heralded by the liberalization of capital markets and politics "as an answer to the economic stagnation of the 1970s" [11]. Friedman's approach has evolved, however. In The World is Flat he adopts the Western-centric perspective that globalization began in 1492, with the voyage of Columbus to the New World, and Europe's subsequent voyages of discovery. Still unwilling to break entirely from his earlier paradigm, Friedman now divides globalization into three eras. The first, Globalization 1.0, which began in 1492 and ended around 1800, was the era of imperialism. The second, Globalization 2.0, which he now says began in 1800 and ended in 2000 (rather than with the onset of the Great Depression), was driven by corporate expansion. Said differently, American and European companies became the driving force behind Globalization 2.0 because they needed new markets and more labor. The final (and current) phase, Globalization 3.0, suggests Friedman, began around 2000 and is marked by the empowerment of the 
individual. Individuals now have the ability to determine for themselves where they fit in the global market place. Moreover, individuals of all backgrounds are being empowered by Globalization 3.0, making this the first phase of globalization, in Friedman's view, truly open to non-Westerners [12,13].

O'Rourke and Williamson, on the other hand, dismiss efforts to "attach globalization 'big bang' significance to 1492 and 1498." Historians that do so, they argue, "are on the side of Adam Smith who believed" that Columbus' discovery of the Americas and Vasco da Gama's rounding of Africa were two of the most important events in recorded history. They are also skeptical of the world-systems approach, which maintains that a single, uninterrupted world system has existed for at least 5,000 years. Based on quantitative data and qualitative inferences, O'Rourke and Williamson instead argue that globalization really took off in the early $19^{\text {th }}$ century. Not only was the world simply incapable of benefiting from the Great Discoveries immediately after the 1490s, but O'Rourke and Williamson find that the model of an open global economy - a prerequisite for globalization in their view - just did not exist prior to 1828 ([8], pp. 24, 44-47).

No doubt modernity has led to the rapid intensification and acceleration of globalization, but each of these arguments gives analytical primacy to economics. In doing so, they adopt a Western-centric perspective on the long-term historical trends associated with globalization. Unfortunately, this constrains and obfuscates globalization's story in an effort to package the process as some kind of modern phenomenon, which ultimately marginalizes the roles that ideational factors, including religion and religious actors, have played in its genesis. Additionally, these arguments are semantically flawed, as Friedman, Smick, and O'Rourke and Williamson, all base their ideas of when globalization started on the idea that globalization itself is a system, or a singular state not subject to differing orders of magnitude. This can be expressed in a simple heuristic: the world either is globalized, or it is not. In other words, they equate globalization with globalized in spite of the fact that it is a process that should be equated more with globalizing. From this perspective Nayan Chanda, of the Yale Center for the Study of Globalization, argues that globalization "is a process that has worked silently for millennia without having been given a name" ([14], p. xi).

André Gunder Frank and Barry K. Gills are likewise hostile to the idea that economic and societal interconnectedness only began 500 years ago. Not only do they dismiss this idea as a product of Eurocentrism, they argue that globalization began vis-à-vis the world system nearly 5,000 years ago, around $2450 \mathrm{BC}$, during the reign of Akkadian King Sargon, who likely had to deal with issues of hegemony, center-periphery relations, and wealth accumulation, just like his more modern peers [15]. Hugh Liebert, however, places the dawn of globalization nearly 2,000 years later, with the conquests of Alexander the Great. Liebert bases this assertion on what he calls the indeterminacy of identity, or the competing allegiances an individual or a political body might have to a strata of competing identities (i.e., local versus universal). Identity lies somewhere between these allegiances, but when one gains relative to the other, as in the case of rising global identity at the expense of national identity, the result can be territorial expansion. Of course, notes Liebert, expansion driven by allegiance to two equal nations instead of by allegiance to separate stratified identity sources can explain why globalization does not always "entail the rise of a universal community." In any event, Liebert sees Alexander as only partially belonging to various identity groups. As a polity, Macedonia was neither Greek nor Barbarian, city nor nation. Consequently, argues Liebert, "[i]t is a desire for esteem within a culture to which Alexander only partially belong[ed] that spark[ed] his initial conquests," ultimately 
making him the "founder of globalization" ([16], pp. 536, 540-43, 547). Indeterminacy of identity may indeed be a source of motivation for would-be globalizers, but the idea that globalization began only with the spread of Hellenic culture to remote parts of Asia fails to account for previous episodes of imperial expansion. Consider, for example, that Ali Farazmand and Jack Pinkowski contest that globalization was first "conceptualized and even realized to a great extent in the ancient world [...] by Cyrus the Great" a full two hundred years prior to Alexander the Great's invasion of Persia and conquest of the former's empire. Thanks to military conquest, the Achaemenid Empire stretched from Greece and Egypt to India, Kazakhstan and East Turkestan (present day Xinjiang) at its zenith, making it the first world-state in history [17].

Chanda, however, adopts the view that globalization is a trend that started at "the beginning of history": ancient empires, modern multinational corporations, NGOs, even tourists, are all just "continuing the processes of integration that began thousands of years ago" during the first great exodus of humanity from Africa in search of food and security ([14], pp. xi-xii, 1-4). Aslan agrees that the economic, social, and cultural changes associated with globalization have been ongoing for centuries, and he even echoes Chanda, saying " $[\mathrm{t}]$ here is a compelling case to be made for considering the process of globalization to have begun when the first humans footslogged out of Africa in search of game and refuge and more temperate climates" ([1], p. 18). This is not a controversial view; Jack Lule says globalization is a grand "historical process as old as humankind" [18], while Karl Moore and David Lewis, who concede that the world today is far different than the world of antiquity, also see the embryonic strands of globalization extending to Roman and pre-Roman times [19]. Globalization could have begun when people first migrated from Africa, as Chanda, Aslan, and Lule evince, but this scenario presents too broad a context to properly delineate the boundaries of globalization. This great migration can be more accurately described as part of the process of civilization, itself an indispensable precursor to globalization. In this sense, civilization connotes the subjugation of nature to humanity, and the construction and expansion of civilizational groupings (not dissimilar to those discussed by Samuel Huntington). Globalization then, is a process that began when these civilizations started interacting economically, politically, militarily and engaging in cultural exchange. In this sense, Chanda's narrative of migration out of a small village in Duniya, a metaphor where the village is analogous to Africa and Duniya represents the Earth writ large, actually tells the story of civilization not globalization. That is, the dawn of globalization could not be accurately portrayed until "a trader walked over the hill" to discover a human settlement distinct from his own, consequently sparking trade between separate civilizations, or when a preacher "ventured out from another of the many villages $[\ldots]$ hoping to teach others about his god" ([14], p. 2).

It may be better to speak of various and distinct globalizations, as Justin Jennings does [20], but by elucidating the long-term history associated with these processes, one can see that globalization is not a distinctly economic (and by extension, modern) phenomenon. Nor is it a distinctly political or military endeavor, as ancient imperialism might suggest. Globalizations are multivariate processes that cannot be hamstrung by an economic or politico-military approach to the subject. Thus, globalization necessitates a polythetic definition that values these subjects alongside ideational factors and cultural exchange. Perhaps this is why Jan Nederveen Pieterse defines globalization as a process of "increasing economic and political connectivity," a growing awareness of "global interconnectedness," and a "host of specific globalization projects that seek to shape global conditions." To Pieterse, these projects 
enable a globalization of culture, which itself facilitates the spread of lifestyles, music, movies, even fashion and cuisine [21]. Jan Aart Scholte, on the other hand, perceives most approaches to globalization as redundant and inadequate, for they fail to "generate new understanding[s]" of globalization. Thus, Scholte defines globalization as:

"the spread of transplanetary - and in recent times also more particularly supraterritorial—connections between people. From this perspective, globalisation involves reductions in barriers to transworld contacts. People become more able - physically, legally, linguistically, culturally and psychologically — to engage with each other wherever on earth they might be.” ([22], pp. 1473, 1478; emphasis added).

Definitions of globalization are legion, even if some are inadequate. Yet, piecemeal from each of them can help glean the full scope of the phenomenon: globalization is a process increasing the political, economic, technological, social, cultural, and ideational interdependence of states and non-state actors, including individuals. From Antiquity to the present day, it has not only involved the transnational spread and blending of capital, technology, commodities, textiles, manufactured products, people, plants, animals, germs and diseases, but also ideas, cultures, and religions. Ultimately, by moving away from an economic-centric definition of globalization, and by extension, a view of globalization limited to the modern era, the agency of non-economic actors in the process can be properly elucidated. Even those who value an economic-centered approach to globalization must admit though, that historically, religion has played a pivotal role as an agent in this process. Indeed, religion and trade were intimately linked along the Silk Road, for example, where both were important globalizing forces.

\section{Religious Actors: Agents of Globalization}

Human movement from one end of Eurasia to another has been going on since prehistoric times, according to Richard Foltz, the author of Religions of the Silk Road: Premodern Patterns of Globalization. This process likely began as Aryans and other people migrating along mountain chains to remain near their water sources stomped out a series of footpaths that would eventually evolve into the Silk Road, This road, a "trans-Eurasian trade-network remembered today for the Chinese silk that once filled its caravans," illustrates that globalization began more than 3,000 years ago as the Silk Road became an important means by which to facilitate trade and cultural exchange in the ancient world ([23], pp. 2-5; [24]).

Although the Jewish diaspora along the Silk Road can be attributed to the Babylonian exile, some scholars speculate that Jews became involved in trans-Eurasian trade as a result. While little evidence exists to support this claim, the liberation of the Jewish community in Babylon by Cyrus the Great probably led to the spread of the community into every Persian territory. From there, it would have been likely, alleges Foltz, for the Jews to insert themselves into trade and commerce. Along the Silk Road, Jewish merchants' religious ideas would have followed them. Though others likely would have avoided converting to Judaism because it was the religion of the Israelites, and they simply were not Israelites, Hebrew names spread as far as modern Turkmenistan. Jews became more influential along the Silk Road in the Common Era; the Radanite sect, for instance, was well respected along the Silk Road, and as such, was capable of moving freely from Roman Gaul to Byzantium, and on to the Turkic 
regions north of the Caspian Sea. Here, the Radanites encountered the Khazars. While their ruler and the general population retained the traditional shamanistic religion of the Turks, the Khazar elite embraced Judaism after their encounters with the Radanites. Even with the spread of Islam, Radanites maintained their privileged status, empowering them to move freely between Christendom and the Islamic World. The Jews may have even settled in China as early as the third century BC. This particular date, cautions Foltz, is questionable, but even so, at least some Chinese Jews believe their communities arrived from Persia between 58 and 75 AD ([25], pp. 30-34).

The great missionary faiths also took advantage of the globalizing effects of the Silk Road to spread their faith systems. According to Subhakanta Behera, the Silk Road presented religious communities with the most efficient, most credible means by which to spread their beliefs throughout Eurasia. Resultantly, missionaries often joined caravans and traders ([26], p. 5078). Missionaries, Foltz explicates:

"latched onto caravans that would take them and their 'spiritual goods' into new lands. As new religious traditions carried by the Silk Road disseminated eastwards and took root along the way, travelers were increasingly able to find coreligionists in even the most far-flung and out-of-the-way places who could provide them with assistance and fellowship, and to whom in return they could bring some contact (and often cash donations) from the outside world." ([23], p. 12).

Buddhism was the first great missionary faith; the Buddhists initially spread from Northern India to Afghanistan and Bengal. Then, via the Silk Road, it finally spread to China. From China, the religion spread to Korea and Japan in the east, and then back west to Tibet. Buddhist missionaries from Kashmir also spread the religion to the Tarim Basin, a region of East Turkestan that spreads into Northern Tibet, Kyrgyzstan, and Tajikistan ([23], pp. 48-49, 56-58; [26], p. 5078).

Reinforcing the idea that religion and trade went hand in hand along the Silk Road (and the idea that religion and globalization have a co-constitutive relationship), Buddhist expansion increased demand for the network's namesake, silk. Silk was a product used extensively in Buddhist ceremonies, so its increased demand actually stimulated the very economic activity that facilitated its spread in the first place ([23], p. 10). Additionally, Buddhism facilitated Indo-Chinese trade in other textiles. Buddhist artifacts were often exchanged for Chinese textiles, because relics were coveted and highly valued as commodities by the Chinese. Due to this reality, Buddhist artifacts were often trafficked throughout the desert trade routes of Central Asia, making the relic trade the foundation of various kinds of commerce ([27], pp. 85, 87-88). Buddhism also spurred the globalization of Indian art and culture. Not only were Indian texts carried to new lands where they were translated into local languages, but Buddhists also inspired a new art movement. The Gandhara tradition, which was a fusion of Greco-Indian artistic styles made possible by the intermingling of Buddhism with the Hellenistic culture seeded in the region by Alexander the Great, was one of globalization's first eclectic movements. One of the most indelible contributions of the Gandhara artistic tradition "was the depiction of the Buddha in human form," which had features influenced by both Hellenistic culture and Indian iconography. Buddha sculptures, murals, and other depictions made thereafter were all based on this artistic fusion. Moreover, the Gandhara art movement was carried into Central Asia, China, and further east, leaving its mark on the various monasteries, grottoes, and stupas erected along the way ([26], p. 5078). 
An Shigao, the first Buddhist monk named in a Chinese source, was a Parthian missionary that arrived in Luoyang in $148 \mathrm{AD}$. With the arrival of Buddhist missionaries in China, and the establishment of the religion, Chinese Buddhists felt a need for direct contact with the sacred sites and texts of their new tradition. Henceforward, Chinese monks started traversing the Silk Road on pilgrimages to India. Eventually, even Korean and Japanese monks materialized in India. With this, the spread of religion sparked the need for religious pilgrimages, which themselves may have sparked the relic trade, given that pilgrims often returned home with artifacts believed to be the bones or teeth of the Buddha ([23], pp. 12, 53-54). Pilgrimage — and tourism more broadly—remain a major force in the globalization of culture even today. They are connected in various ways: pilgrimage and tourism vis-à-vis globalization both deal with a massive movement of people, capital, and ideas across borders ([28], p. 16), but religious pilgrimages especially, are serious events. Christians, like their Buddhist predecessors, are often engaged in pilgrimages to holy sites, but they are not alone in the practice of pilgrimages. The hajj requires that every adult male who is physically and financially capable of completing the journey travel to Mecca, the Muslim holy city, annually after Ramadan. Of course, this is not always feasible, but Muslims are expected to undertake the hajj at least once in their life. The hajj gives Muslims the opportunity to experience what John L. Esposito terms "the underlying unity and equality of a worldwide Muslim community that transcends national, racial, economic, and sexual differences." The hajj represents an incredible opportunity, therefore, for members of the transnational Islamic community to commune with one another. Thus, at least two million people descend on Saudi Arabia for this holy journey every year [29].

As was the case with Buddhism though, missionary activity generally precedes the practice of pilgrimage, and Chanda contends that the appearance of Jesus of Nazareth heralded the world's second wave of proselytizing and missionary activity ([14], p. 119). Accordingly, Christianity spread throughout the Roman Empire in the west, and returning to the matter of the Silk Road, on to India and China in the East. After the execution of Jesus, his Apostles dedicated themselves to carrying his message throughout the world. Douglas K. Stuart says that the Apostles sold their earthly belongings, and pooled their earnings to finance evangelistic missionary trips outside of Palestine. Take, for example, Saint Paul, who launched his mission to the gentile world from Syria, before moving by caravan and ship to Greece, and eventually to Rome itself [30].

Some thousand years later, at the Council of Clermont on 27 November 1095, Pope Urban II (r. 1088-1099) called the First Crusade. The crusades clearly illustrate the role of Christianity as a driving force in globalization, though the real reason may not be immediately apparent. First, some historians believe that the crusades were "Europe's first colonial wars, a kind of proto-imperialism visited on the Muslim people" ([31], p. 119). While this idea was supported by demographic trends that convinced historians Europe was in need of more land, it gained popularity in an era of anticolonialist sentiment. Arab nationalists, for instance, adopted the rhetoric of "crusading imperialism." Further evidence for this claim is based on three facts. First, the Italian city-states gained a privileged economic position along the Levantine coast. Second, the poor were easily persuaded to leave their fields in favor of fighting for the Holy Land. And third, many coastal territories were eventually settled after the western Europeans conquered them. However, these so-called colonies would have been 
nothing more than religious colonies, ${ }^{1}$ if that. The Europeans of western Christendom never set out to establish the kind of imperialist politico-economic edifice that characterized later European adventurism. Their trek to the Levant truly was a journey inspired by religious ideas ([31], pp. 11-12; [32]). ${ }^{2}$

The crusades were, first and foremost, a pilgrimage to Jerusalem, which, as Christianity's holiest site, was the object of the First Crusade. Even in Muslim-controlled Jerusalem, Christians were allowed to practice their faith freely because pilgrims were an integral source of profit. Moreover, pilgrimage to the city was so important for Christians that by the time of the First Crusade, knights even had to take a pilgrim's vow prior to their voyage to the Levant; they each swore to visit the Holy Sepulcher, Christ's tomb. With that, a pilgrim army was born. However, while the First Crusade was meant for Europe's knights and warriors, many others (women, the sick, and the poor, for example) joined and traveled to the Middle East because the crusade was preached and framed, not as a war, but as a pilgrimage ([23], p. 12; [31], pp. 5, 9-11). Cultural exchange, missionary activity, and pilgrimages (like the hajj or First Crusade) are just a few areas where religious actors have served to promote the process of globalization. Yet, many others have been agents in its backlash. What explains this apparent paradox?

\section{Homogenization and the Globalization Backlash}

One of the alleged second order effects of globalization is homogenization. The homogenization thesis posits that globalization will lead to a linguistic, religious, and cultural convergence that ultimately reduces diversity everywhere. Speaking in hyperbole, Friedman asserts that "because globalization as a culturally homogenizing [...] force is coming on so fast, there is real danger that in just a few decades it could wipe out the ecological and cultural diversity that took millions of years of human and biological evolution to produce" ([2], p. 278). Scholte points out that indigenous people's heritages are being erased, and that languages are dying at a rate as alarming as animal extinction ([22], p. 1495). Some might recall Huntington's seminal work, The Clash of Civilizations and the Remaking of World Order: different civilizations rise and fall, merge and divide, and even end up "buried in the sands of time." Historically speaking, there have been as many as twenty-four unique civilizations, but today that number has fallen to eight [33]. Friedman suggests this is a result of globalization creating a single, uniform global market place. Its "huge economies of scale that reward doing the same business or selling the same product all over the world all at once" homogenize global patterns of consumption. Resultantly, different places all over the world are starting to look alike: whether it is Qatar or Kansas, Taco Bell, MTV, Disney, Marriott, McDonalds, and Microsoft are nigh omnipresent ([2], pp. 278-79). In this view, Americanization is conflated with globalization and perceived as a war on culture. It is American-style consumer culture that erodes values and culture, replacing them with the "drab and uniform Americanized culture" of Coke and Starbucks. Consequently, Americanization subverts

1 The Western and Eastern Churches had, over time, developed their own rites. Crusader conquests could only be described as religious colonies insofar as they became beachheads in the East for the Roman rite.

2 This view also may have its origin in the positivist, post-Enlightenment view of religiosity. Thomas Madden speculates that "it is too often presumed that medieval men and women could not possibly take seriously the pious words they uttered and wrote." Religion, goes the reasoning, would have been more of a diversion or ruse for those that sought to profit in this life ([31], 11-12). 
non-Western cultures by "encouraging people to buy American goods and services," which ultimately "undermines deep-rooted communal values" [34].

As old as globalization itself, homogenization is an historical process often linked to the expansionary policies of hegemonic powers, especially on a regional scale. Recall the Romanization of Europe, for instance, or the Islamification of Central Asia, North Africa, and the Middle East ([2], p. 9). Prior to the emergence of Islam, the Silk Road (and Central Asia more generally) was viewed as a religious and cultural melting pot, influenced by the diverse ideas of Christians, Jews, Zoroastrians, Manicheans, and Buddhists. It was a refuge for heretics, such as the Nestorian Christian sect; and powers like the Mongolian Empire, supported policies of pluralism due to the natural diversity of the trade network. The rise of Islam though, eventually supplanted this diversity with one of the most thoroughly homogenized cultures in the world. Muslim political power, combined with Muslim control of "trans-Asian trade" factored into the Islamification of Central Asian culture, as did the influence of "charismatic Sufi preachers." Of course, Muslim dominance of commercial activity was the primary factor leading to the homogenization of Central Asia and the Silk Road, for, as Richard Foltz maintains, "[a] businessman might well feel that becoming a Muslim would facilitate contacts and cooperation with other Muslim businessmen both at home and abroad." This was due in part to the favoritism granted to Muslim traders by Muslim leaders, but even so, taken together with the process of assimilation, conversion for commercial reasons helps explain the cultural homogenization of the region ([23], pp. 59, 91-93, 106-07, 127).

With globalization comes rapid change, a fact that challenges social structures and cultural mores. As such, globalization has generated a widespread, substantial backlash fueled by anxiety and anger. Some fear they are ill-equipped to succeed in the workplace as a result of globalization. Others find themselves alienated - their identities challenged by the global forces of cultural homogenization. The most visible manifestation of the globalization backlash occurred as raucous protestors descended on Seattle in late 1999, to protest against a WTO summit. It was here, at the so called "Battle of Seattle" that the backlash united many disparate groups and organizations with varied (even contradictory) interests. Labor unions joined forces with environmentalists, animal rights activists, longshoremen, students, anarchists, organic food activists, aid-lobbyists, and consumer-rights advocates. According to Friedman, groups like the AFL-CIO "covertly funded a lot of the advertising on behalf of the demonstrations in Seattle to encourage grass-roots opposition to free trade," and undoubtedly to help forge such a diverse and unlikely alliance ([2], pp. 329, 334, 337; [35]). As a result, one of the interest groups drawn to Seattle was the Jubilee Network, then known as Jubilee 2000.

Jubilee was a network of faith groups, churches, televangelists, NGOs, celebrities, and individuals around the world inspired by Leviticus 25, which mandates the freeing of slaves, the return of land, and debt forgiveness every fifty years in the year of the Biblical Jubilee. 2000 ushered in the most recent Year of Jubilee, and with it, a clarion call from faith groups for the international community to forgive the crushing debt load of the developing world. The Jubilee Network received wide support in the UK-from the Church of England, then-Prime Minister Tony Blair, and then-Chancellor of the Exchequer Gordon Brown - and beyond: even Pope John Paul II, U2's Bono, U.S. President Bill Clinton, and televangelist Pat Robertson threw their support behind the network's debt relief initiative. Hence, at Seattle and other major economic forums, including G8 Summits, World Bank meetings, and 
IMF meetings, Jubilee joined protestors to decry the "evils" of globalization, and to subject these deliberations to moral scrutiny [36].

While this example demonstrates that religious actors are not alien to the globalization backlash, these same actors - who probably received the least attention in the aftermath of the Battle of Seattlehave stood in opposition to globalization, not for decades, but for centuries. Said differently, the globalization backlash began long before the Battle of Seattle, and religious actors have, in fact, been among some of the most vocal anti-globalizers. There is an asymmetric power dynamic often times at work in the process of globalization, linked to the hegemonic powers typically associated with the phenomenon. So, today, globalization is seen in some corners of the globe as Americanization, while some living in the first century might have called it Romanization. In the case of the former, the backlash to globalization may manifest itself in Anti-American protests. In the latter, the Sicarii epitomize the globalization backlash. A first century splinter of the Jewish Zealots, the Sicarii have been characterized as one of the earliest known examples of a terrorist organization for their use of "unorthodox tactics such as random murders in the midst of large crowds" in an effort to end the Roman Empire's occupation of Judea [37]. The backlash might also target the exploitation of foreign populations. Here, the Dominican Friars of the Viceroyalty of New Spain are worthy of note, due to their defense of the Native American Indian populations of Mesoamerica. They preached against the mistreatment of the Indians by the conquistadors, insisting that the natives had the ability to reason and that they had souls. They also invoked Biblical commandments for the conquistadors to love the natives as themselves, and they preached against the encomienda, a tributary system responsible for reducing the native populations to slavery. Dominicans, such as Bartolomé de Las Casas, worked tirelessly to protect the Indians, and eventually secured the passage of laws abolishing the encomienda system ([38], p. 69; [39,40]). While the examples of the Sicarii and the Dominicans might not ordinarily come to mind when thinking about the globalization backlash, they clearly demonstrate that religious actors have been lashing out against the forces of globalization for centuries.

The backlash to globalization also reinforces the idea that it makes sense to speak more of globalizations than globalization, for the crusades - a globalizing force as noted above — might also be viewed through the lens of the globalization backlash. After all, Byzantium had been under siege for some time. Both Arab and Turkish Muslim invaders had been harassing the empire, even conquering Syria, Palestine, and Armenia. Islam itself was the globalizing force. From the Arabian Peninsula, it had created an empire that stretched from North Africa in to Spain, on to India and Central Asia. Arabian economic life was tied to raiding. When clans built nonaggression pacts with their neighbors, it prevented raiding. The spread of Islam over the Arabian Peninsula was facilitated by the submission of various clans to Muhammad, which impacted the Arab economy even after the Prophet's death, forcing Muslims "to launch forays beyond the Arabian Peninsula into Byzantine and Persian territory." Both Muslims and non-Muslims view the expansion of Islam in hindsight as the product of religious zeal. Of course, the attraction of ideas cannot be ignored, but the "Arab armies of the time were simply doing what they were naturally acculturated to do, what the economic conditions of their homeland had always constrained them to do" ([23], pp. 86-87). Thus, Islam became an expansive, globalizing force, which meant conflict with the Byzantines. The Byzantines had, nevertheless, held on to Greece and Asia Minor, but Emperor Alexius I Comnenus (r. 1081-1118 AD) had to turn to Rome for help. He sent an envoy to the pope to request assistance. Because the Byzantines "had lost much in the storm 
of Muslim expansion," the First Crusade was conceived as a war of expulsion! It was meant to help recapture lost Byzantine territory and drive Muslim expansionists out of the region ([31], pp. 4-7). Thus, in this respect, the First Crusade was as much a case of counter-globalization as it was an example of the globalization backlash.

\section{The Modern Religious Backlash}

More modern examples also illustrate this point. Although the current religious resurgence may make the importance of religion seem obvious, experts living during the 1960s and 1970s believed that some of the forces of globalization-urbanization, modernization, technological advancement, democratization - would be accompanied by secularization. Unfortunately, the globalization of secularism became a chief source of anti-American, anti-Western sentiment in pre-revolutionary Iran. Before 1979, foreign policy and intelligence elites may have missed this because "they did not think religion mattered in world politics" ([6], pp. 7, 10-11, 13-14; [41], p. 12; [42]). However, in an effort to modernize Iran, Reza Shah Pahlavi and his son, Mohammad Reza Shah Pahlavi, instituted a forceful top-down secularization program that alienated the nation's clerics, leading Ayatollah Ruhollah Khomeini, for example, to criticize the shah's regime as unjust, corrupt, anti-Islamic, and the object of jihad, rousing revolutionary discontent ([6], pp. 11-12; [43]).

The backlash against globalization, or to be more precise, the Westernization of the Pahlavi regime, was an outgrowth of clerical and societal disillusionment with what Ahmad Fardid termed in Persian, gharbzadegi. Gharbzadegi, or "Westoxication" in English, "conveys both intoxication - the infatuation with the West - and infection - the poisoning of westernization of an indigenous culture." The term was coined by Fardid in his lectures at the University of Tehran, but it gained popularity with the publication of Jalāl Āl-e Ahmad's book, Gharbzadegi ([44], pp. 1, 19n; [45]). ${ }^{3}$ The purpose of the book was to make Iranians aware of the issue of Westoxication, ${ }^{4}$ something A 1 -e Ahmad did by contrasting the wealthy, developed West with the poor, underdeveloped East. In it, he laments that the two-way exchange of wealth, culture, ideas, and technology that once existed between East and West has been displaced by turning Easterners into consumers of Western products and Western culture. He accuses Westernizing Iranian elites of corruption, and likens the cultural dependence on the West to the economic dependency so prevalent in the Third World. In this way, asserts Brad Hanson, Gharbzadegi became a "harbinger of many of the North-versus-South debates of the 1960s and 1970s," including the Third World's demand for a new international economic order, and its efforts to combat cultural imperialism. Āl-e Ahmad ties all of this to the forcible injection of Western technology into Iran. For him, the technology of the West is both intimidating and exploitive, enabling Iran's subjugation. The best way, in his view, to throw of the yolk of the West would be to become masters and builders of the technology, rather than hapless consumers of products manufactured elsewhere ([44], pp. 8-12). Āl-e Ahmad was a secularist, so it may appear at first blush that his efforts

3 Gharbzadegi renders variously into English as "Occidentosis," "Weststruckness," "Westomania," "Westernitis," "Westamination," "Euromania," and "Blighted by the West."

4 To Āl-e Ahmad, Westoxication was not a problem exclusive to Iran. It was, in fact, "a worldwide disease" endemic to globalization. He noticed, specifically, that the world of Islam had fallen prey to gharbzadegi, but this was a disease that afflicted the "East" in its entirety ([44], p. 9). 
to fight Westoxication had little to do with the backlash to globalization. Indeed, he probably would have wanted it that way; his work, after all, "dismisses religion and the ulama as a reactionary and ineffective bulwark against Western domination." During the hajj however, Āl-e Ahmad intensely reexamined religion and fought a serious internal struggle, questioning matters of faith, but ultimately leading him to accept Islam into his life. That this life changing event was the result of his attending an event that was itself an outgrowth of an earlier era of globalization is ironic, but he finally came to see Islam as "a vital, native, non-Western part of Iranian identity with a potential for effective resistance to 'Westoxication,"' and as a powerful force for inspiring indigenous opposition to Westernization ([44], pp. 1, 12, 19).

'Ali Shari'ati, one of Āl-e Ahmad's peers, and a lay religious leader that sympathized with the Third World's struggle against cultural, political, and economic imperialism, advocated for religious involvement in the backlash to globalization throughout his career. However, he rejected Marxism, surely an influence behind Āl-e Ahmad's secularism, and advocated for "a politically active, even revolutionary, revitalized Shi'ism, indigenous to Iran, struggling for social justice, as a third way between Westernization and Marxism" ([44], pp. 2, 19). Needless to say, Ayatollah Khomeini eventually usurped the themes of Westoxication, and incorporated them in his own teachings. In a letter to Muslims gathered for the hajj, Khomeini lambasted "the foul claws of imperialism" for poisoning Persian culture, even at the level of town and village. Inevitably, Khomeini even borrowed the term, gharbzadegi, using it in his lectures, letters, and proclamations to appeal to a "wide base of Iranians who felt disenchanted by the government's pro-Western policies" ([46], p. 195; [47,48]). Clearly, with respect to Westoxication, the Islamic Revolution of 1979 was in many ways, part of the backlash against globalization.

The case of the Iranian Revolution is one that saw anti-Westernization conflated with anti-globalization, but as the case of Jubilee 2000 demonstrated above, the globalization backlash is not always targeted against the West. As a matter of fact, it can emanate from the West. Although the American Christian nationalist movement did not metastasize until the 1960s, themes of anti-globalization started mingling with Christian thought, especially in prophecy driven conspiracy theories, much earlier. For some conspiracy theorists, organizations like the CFR represent a modern incarnation of the Illuminati. According to Gregory S. Camp, the CFR is perceived as "a front for international government and [international] banking" ([1], p. 84; [49], p. 73). In fact, notes Camp, some of the founding members of the CFR supported the LON, probably as a corollary to their belief "that global government is the only solution to the world's troubles." In other words, the CFR has been supportive of political globalism, and in some cases, one-world government, as a means of resolving the world's otherwise unresolvable problems ([49], p. 76). Many fundamentalist Christians fear this kind of globalization though, because in their worldview it represents the fulfillment of Biblical prophecy. It is expected that world government will usher in the reign of an evil anti-Christ that will deceive Christians into abandoning their faith and salvation. Thus, political globalism is not something favored by Christians as a sign of prophecy fulfillment; it is instead something that must be opposed. After World War I, preachers found a market thirsty for prophecy writing. Convinced that the last days were nigh, these writers speculated that "a ten-nation confederacy that would ultimately produce the true Beast," or anti-Christ, would appear as an outgrowth of the LON. Given the CFR's support for the 
League - and for globalism in general - it is no wonder that Christian conspiracy theorists would target the organization ([49], p. 78; [50]).

Interestingly, the CFR conspiracy has been entangled with U.S. partisan politics; it is at the domestic level where conservative Christian conspiracy theorists plan their stand against globalism. Gary Allen, a conspiracy expert at the John Birch Society, accuses the CFR of promoting a leftward turn in U.S. foreign policy to promote world government, saying that it has done so by completely undermining the U.S. Department of State and subverting the armed forces. Meanwhile, others link U.S. President Barack Obama to a long line of globalizers, including Woodrow Wilson, and Franklin D. Roosevelt, all Democrats! In doing so, they praise conservative politicians for opposing globalism, and they incite their fellow Christians to action at the polls, where they are expected to vote against the Democratic Party. This is made evident by the fact that renowned preachers, such as Pat Robertson, accuse an alliance comprised of the CFR, the UN, and the White House, of surrendering American rights, religion, and sovereignty to a would-be world government ([51]; [52], pp. 123-24).

The anti-globalization backlash manifests in protests, but it can simply take the form of anxiety, which is what has happened in these conspiracy theories. Yet, it does not always emanate from one point of the politico-ideological spectrum either. While Grant R. Jeffrey, another preacher, prolific writer, and televangelist, may expand the world government myth to encapsulate the problem of global warming in his recent book, The Global-Warming Deception, some liberal criticisms of unfettered free-market capitalism might also be characterized by this globalization anxiety. In novels, such as Dani and Eytan Kollin's The Unincorporated Man and Max Barry's Jennifer Government, readers are presented with dystopian visions of the future wherein globalization vis-à-vis capitalism has run amuck. Based on the Biblical story of Noah, wherein God promises not to flood the Earth ever again, Jeffrey, on the other hand, joins a chorus of conservative global warming deniers to argue that the global warming hoax is part of the conspiracy to establish the one-world government [53]. What is more fascinating about such works as Jeffrey's though, is that they add a chiliastic dimension to the globalization backlash that can only exist among the narratives of religious actors.

The religiously motivated backlash against globalization has manifested itself in many ways: as peaceful social justice movements, such as that of the Jubilee Network; it has provoked violence, as in the case of the Sicarii Zealots; it has opposed exploitation, as in the cases of the Dominican Friars and the Iranian Revolution of 1979; it has devolved into paranoid conspiracism in an effort to impact domestic level politics, as in the case of the U.S. Christian nationalists. Remembering again the fact that religion cannot be treated as a monolith, one cannot simply assume that globalization elicits identical responses from all religious actors, or that it even necessarily has to regard globalization, in whatever incarnation it may take, as a threat. Sometimes, it can simply elicit anxiety, sometimes it elicits something more; and, as the agent-opponent paradox reveals, sometimes globalization is something actively pursued by religious actors. Regardless of its form though, this backlash is the result of globalization's more indiscriminate ability to victimize actors of all kinds. In these cases, globalization is a powerful, disruptive force that undermines traditional culture, usually seeking to replace it with a universalized culture exported to the rest of the world through the power of commercial activity. The resulting insecurities provoked in religious actors are thus among the drivers of the globalization backlash. 


\section{Conclusions}

Why does the agent-opponent paradox matter? Aslan addresses this problem in the context of a single case-study, and with the depth and analytical rigor that only a book length treatment can allow for. In How to Win a Cosmic War, he argues that jihadists such as those found in Al Qaeda, are agitating against one form of globalization-Westernization - even though they are at the same time products of this phenomenon. The inherent irony here, is that they even utilize the tools and techniques (satellite television and the internet, for instance) produced as a result of the forces of globalization to achieve their own globalizing aim of establishing a new transnational, borderless, and Islamic caliphate. Some religious actors have opted for non-violence to oppose the established global order. American Christian nationalists turn to the polls to protect their own sovereignty, while groups like Jubilee 2000 have engaged in mostly peaceful protests targeting exploitative policies. But actors like Al Qaeda, like those of the distant past including the Sicarii, have opted to use violence as a means by which to confront the asymmetric power dynamics of globalization that have left them feeling victimized. Globalization may yield incredible dividends for some religious actors, but because others find themselves victimized by the powerful forces of homogenization and cultural disruption, some of these groups will undoubtedly create security challenges in the future.

Religious actors have been agents of globalization for centuries. The examples enumerated herein deserve more attention, but they are just that, examples. One could easily also look to the vast role Christian missionaries played in the run up to the colonial era, as in Buganda or Hawaii; or one could consider the role of modern missionaries today, such as Christian Evangelicals. Here too, even agents of globalization can create security challenges with which some countries, like the U.S., must be concerned. For example, some Christian Evangelicals have been sneaking into post-invasion Iraq over the last several years in an effort to spread their faith to the Middle East without regard for the fact that their intrusion might provoke hostility. Of course, this should not denigrate the fact that missionaries (and the missionary spirit) have made a prolific contribution to globalization and cultural exchange, as in the case of those African missionaries dispatched to North America to combat secularism and to fill empty church pews. However, this assertion holds true of pilgrimage, too. Remember, it was during the hajj when Âl-e Ahmad discovered the efficacy of Islam in countering Westernization; it was during the hajj when Ayatollah Khomeini also started incorporating the themes of gharbzadegi into his teachings. Each case introduced above is absolutely unique, and there are of course, unrelated domestic factors at play in them all, especially in Iran, that contributed to their specific outcomes. Yet, while there are a number of reasons the Pahlavi regime collapsed, the globalization backlash can be counted among them. Indeed, in and of itself, the fact that Āl-e Ahmad and Khomeini were using the hajj to convey and hone their ideas is innocent enough. Through their actions, however, they gave agency to Islam and helped foment resistance to the regime and Westernization. Of course, pilgrimages are more than just events that inspire revolutionary ideas; they are legitimate displays of religiosity and ought to be treated with reverence by the faithful. That does not mean though, that the international community can ignore the security dimensions of religious pilgrimage. Jews and Christians traveling to Israel, for instance, must worry about acts of terrorism and the dangers associated with the Israel-Palestine conflict. Saudi Arabia has to be concerned with efforts on the part of Iran to manipulate Shi'ite pilgrims as a means of stirring discontent, or inspiring protests for Iranian propaganda campaigns, in 
an attempt to place pressure on the Saudi regime. Meanwhile and finally, the ISAF in Afghanistan has to help facilitate a safe environment for Afghan pilgrims to leave the nation as part of the hajj until the U.S. military and coalition forces fully withdraw from the country [54-56].

Religion and globalization share a strange and paradoxical, yet mutually reinforcing relationship. Some religious actors play and have played a role in driving globalization for centuries, a fact made more obvious when the economic-centric approach to defining religion has been dismissed. Of course, even if one considers the Age of Discovery to be the origin of globalization, one must recall that even it was conceived of as a quest for "God, Gold, and Glory." And though globalization can have dramatically negative effects on some religious actors, inciting them to join the anti-globalization backlash, an as of yet unspoken aspect of the agent-opponent paradox is that this phenomenon also has a number of positive effects on religion. While scholars of the mid- $20^{\text {th }}$ century may have dismissed religion as a primitive manifestation of superstition, thinking that the forces of globalization would lead to religion's demise, the effects of cultural exchange and ideational globalization has led to its proliferation, and also to the increasing prevalence of eclectic movements, as in Japan, which is home to many religious eclectics that borrow from a variety of traditions. This is also true of ancient movements, like the Gandhara, and more modern NRMs, like those of the Cao Dai, the Baha'i, UFO cults, and Scientologists. NRMs, that is, sprout from globalization like plants from the earth. Again, the caveat is, of course, that even NRMs can pose security challenges, further demonstrating the reason the agent-opponent paradox matters. Thanks to globalization religion is resurgent with a vengeance, but as the U.S.'s experience with some NRMs, such as the Branch Davidians in Waco, Texas, illustrates, this resurgence includes the formation of sometimes dangerous groups that cannot be ignored. Historically, religions and religious actors of all kinds have clearly been vital to the process of globalization, and as the narrative above demonstrates, they still can be. However, if these security challenges are to be ameliorated by the international community, the globalization backlash should be taken seriously, and the grievances of disgruntled religious actors should be addressed. This can be accomplished first by partnering with social justice movements like the Jubilee Network, second by engaging in interfaith dialogue with religious actors of all kinds, and finally by employing the resulting proposals of such partnerships and dialogue in an attempt to reduce the more damaging effects, like cultural disruption, of globalization.

\section{Acknowledgements}

Thanks are due to Hal E. Wert, Jeannie Herrington, and two anonymous reviewers for their helpful comments on this article, and also to the One-University Open Access Author's Fund at the University of Kansas for generously funding the publication of this article.

\section{References}

1. Reza Aslan. How to Win a Cosmic War: God, Globalization, and the End of the War on Terror. New York: Random House, 2009.

2. Thomas L. Friedman. The Lexus and the Olive Tree: Understanding Globalization. New York: Anchor Books, 2000. 
3. John O'Sullivan. The President, the Pope, and the Prime Minister: Three Who Changed the World. Washington, D.C.: Regnery Publishing, Inc., 2006.

4. Brent J. Steele. Ontological Security in International Relations: Self-Identity and the IR State. London: Routledge, 2008, 150.

5. W. Richard Comstock. "Toward Open Definitions of Religion." Journal of the American Academy of Religion 52 (1984): 499-517. doi:10.1093/jaarel/52.3.499.

6. Monica Duffy Toft, Daniel Philpott, and Timothy Samuel Shah. God's Century: Resurgent Religion and Global Politics. New York: W. W. Norton and Company, 2011.

7. Economic and Social Commission for Western Asia. Annual Review of Developments in Globalization and Regional Integration in the Countries of the ESCWA Region, 2002. New York: United Nations Publications, 2003, 2.

8. Kevin H. O'Rourke, and Jeffrey G. Williamson. "When Did Globalization Begin?" European Review of Economic History 6 (2002): 23-50. doi: 10.1017/S1361491602000023.

9. Merriam-Webster, n.d. "Globalization." http://www.merriam-webster.com/dictionary/globalization.

10. Susanne Hoeber Rudolph. "Introduction: Religion, States, and Transnational Civil Society." In Transnational Religion and Fading States, edited by Susanne Hoeber Rudolph and James Piscatori. Boulder, Colorado: Vintage, 1997, 1-24.

11. David M. Smick. The World is Curved: Hidden Dangers to the Global Economy. New York: Portfolio, 2008, 1-5, 15, 34-44, 214.

12. Thomas L. Friedman. The World is Flat: A Brief History of the Twenty-First Century. New York: Macmillan, 2007, 8-10.

13. Thomas L. Friedman. "It's a Flat World, After All.” New York Times Magazine, 3 April 2005. http://www.nytimes.com/2005/04/03/magazine/03DOMINANCE.html?_r=1\&pagewanted=all\&p osition $=$.

14. Nayan Chanda. Bound Together: How Traders, Preachers, Adventurers, and Warriors Shaped Globalization. New Haven, Connecticut: Yale University Press, 2007.

15. André Gunder Frank, and Barry K. Gills. The World System: Five Hundred Years or Five Thousand? London: Routledge, 1999, xv, 3-5.

16. Hugh Liebert. "Alexander the Great and the History of Globalization." The Review of Politics 73 (2011): 533-60. doi: http://dx.doi.org/10.1017/S0034670511003639.

17. Ali Farazmand, and Jack Pinkowski. Handbook of Globalization, Governance, and Public Administration. Boca Raton, Florida: CRC Press, 2007, 13-14.

18. Jack Lule. Globalization and Media: Global Village of Babel. Lanham, Maryland: Rowman and Littlefield, 2012, 23.

19. Karl Moore, and David Lewis. The Origins of Globalization. New York: Routledge, 2009, xii-xvi.

20. Justin Jennings. Globalizations and the Ancient World. Cambridge: Cambridge University Press, 2011.

21. Jan Nederveen Pieterse. Globalization and Culture: Global Mélange. Lanham, Maryland: Rowman and Littlefield, 2009, vii, 16-17; emphasis removed.

22. Jan Aart Scholte. "Defining Globalisation." The World Economy 31 (2008): 1471-1502. doi: 10.1111/j.1467-9701.2007.01019.x. 
23. Richard Foltz. Religions of the Silk Road: Premodern Patterns of Globalization, 2nd ed. New York: Palgrave Macmillan, 2010.

24. Luke M. Herrington. "Review - Religions of the Silk Road." E-International Relations, 18 April 2012. http://www.e-ir.info/2012/04/18/review-religions-of-the-silk-road/.

25. Richard Foltz. "Judaism and the Silk Route." The History Teacher 32 (1998): 9-16.

26. Subhakanta Behera. "India's Encounter with the Silk Road." Economic and Political Weekly 37 (2002): 5077-80.

27. Stephen F. Dale. "Silk Road, Cotton Road, or... Indo-Chinese Trade in Pre-European Times." Modern Asian Studies 43 (2009): 79-88. doi:10.1017/S0026749X07003277.

28. Kevin A. Griffin. "The Globalization of Pilgrimage Tourism? Some Thoughts From Ireland.” In Religious Tourism and Pilgrimage Management: An International Perspective. Edited by Razaq Raj and Nigel D. Morpeth. Cambridge, Massachusetts: Cab International, 2007, 15-34.

29. John L. Esposito. Islam: The Straight Path. Oxford: Oxford University Press, 1998, 91-92.

30. Bram Roos, and Michael E. Katz, prods. Christianity: The First Two Thousand Years. New York: A\&E Television Networks, 2001, DVD.

31. Thomas F. Madden. A Concise History of the Crusades. Lanham, Maryland: Rowman and Littlefield, 1999.

32. Jonathan Riley-Smith. The First Crusaders, 1095-1131. Cambridge: The Press Syndicate of the University of Cambridge, 1997, 15-17.

33. Samuel P. Huntington. The Clash of Civilizations and the Remaking of the World Order. New York: Simon and Schuster Paperbacks, 2003.

34. Jeffrey Haynes. An Introduction to International Relations and Religion. Harlow, England: Person Longman, 2007, 75-76.

35. "The Battle of Seattle." The Economist, 25 November 1999. http://www.economist.com/node/ 261578.

36. Jim Wallis. God's Politics: Why the Right Gets it Wrong and the Left Doesn't Get It. San Francisco: Harper San Francisco, 2005, 272-78.

37. Dan G. Cox, John Falconer, and Brian Stackhouse. Terrorism, Instability, and Democracy in Asia and Africa. Boston: Northeastern University Press, 2009, 10.

38. Martin Austin Nesvig. "The 'Indian Question' and the Case of Tlatelolco." In Local Religion in Colonial Mexico, edited by Martin Austin Nesvig. Albuquerque, New Mexico: University of New Mexico Press, 2006, 63-89.

39. Encyclopedia Britannica. "Western Colonialism." Encyclopedia Britannica's Guide to Black History, n.d. http://www.britannica.com/blackhistory/article-25872.

40. Encyclopedia Britannica, n.d. "Encomienda." http://www.britannica.com/EBchecked/topic/186567/.

41. Douglas Johnston, and Brian Cox. "Faith-Based Diplomacy and Preventative Engagement." In Faith-Based Diplomacy: Trumping Realpolitik. Edited by Douglas Johnston. Oxford: Oxford University Press, 2003, 11-29.

42. James A. Bill. The Eagle and the Lion: The Tragedy of American-Iranian Relations. New Haven, Connecticut: Yale University Press, 1988.

43. John L. Esposito. Islam and Politics. Syracuse, New York: Syracuse University Press, 1984, $120-21$. 
44. Brad Hanson. “The 'Westoxication' of Iran: Depictions and Reactions of Behrangi, Āl-e Ahmad, and Shari'ati." International Journal of Middle East Studies 15 (1983): 1-23. doi: http://dx.doi.org/10.1017/S0020743800052387.

45. Frederick Mathewson Denny. An Introduction to Islam. Upper Saddle River, New Jersey: Pearson Prentice Hall, 2005, 364.

46. Ruhollah Khomeini. "Message to the Pilgrims." In Islam and Revolution: Writings and Declarations of Imam Khomeini (1941-1980). Edited by Hamid Algar. Berkley, California: Mizan Press, 1981, 195-99.

47. Hamid Dabashi. Theology of Discontent: The Ideological Foundation of the Islamic Revolution in Iran. New York: Transaction Publishers, 2006, 74.

48. S. Waqar Hasib. "The Iranian Constitution: An Exercise in Contradictions." Al Nakhla 3 (2004): 1-12. http://fletcher.tufts.edu/Al-Nakhlah/Archives/ /media/Fletcher/Microsites/al\%20Nakhlah/ archives/pdfs/hasib.ashx.

49. Gregory S. Camp. Selling Fear: Conspiracy Theories and End-Times Paranoia. Grand Rapids, Michigan: Baker Books, 1997.

50. Steve R. Rock. Faith and Foreign Policy: The Views and Influence of U.S. Christians and Christian Organizations. New York: Continuum International Publishing Group, 2011, 145.

51. Michael Wala. The Council on Foreign Relations and American Foreign Policy in the Early Cold War. Providence, Rhode Island: Berghahn Books, 1994, xi.

52. Michael Barkun. "The 'New World Order' and American Exceptionalism." In Mapping the End Times: American Evangelical Geopolitics and Apocalyptic Visions. Edited by Jason Dittmer and Tristan Sturm. Burlington, Vermont: Ashgate Publishing, 2010, 119-32.

53. Grant R. Jeffrey. The Global Warming Deception: How a Secret Elite Plans to Bankrupt America and Steal Your Freedom. Colorado Springs, Colorado: Water Brooks Press, 2011, 3-5, 187-88.

54. Noga Collins-Kreiner, Nurit Kliot, Yoel Mansfield, and Keren Sagi. Christian Tourism to the Holy Land: Pilgrimage During Security Crisis. Burlington, Vermont: Ashgate Publishing, 2006, xiii.

55. Anthony H. Cordesman. Saudi Arabia: National Security in a Troubled Region. Washington, D.C.: Center for Strategic and International Studies, 2009, 20, 274.

56. "ISAF Ensures Afghans' Smooth Passage to Mecca." The Maple Leaf 11 (2008): No. 41. http://www.forces.gc.ca/site/commun/ml-fe/article-eng.asp?id=4920.

(C) 2013 by the author; licensee MDPI, Basel, Switzerland. This article is an open access article distributed under the terms and conditions of the Creative Commons Attribution license (http://creativecommons.org/licenses/by/3.0/). 